\title{
THE DEVELOPMENT OF THE TRANSIT TRADE OF IRAN IN THE TRIANGLE OF RUSSIA, OTTOMAN EMPIRE AND IRAN IN THE SECOND HALF OF THE $19^{\mathrm{TH}}$ CENTURY
}

\author{
Mehmet ÇETİN*
}

\begin{abstract}
The transit trade of Iran had great importance for both the Ottoman Empire and the European economies for accessing raw materials. This trade had largely been under the control of the Ottoman Empire until the last quarter of the $18^{\text {th }}$ century. The loss of this monopoly according to the Treaty of Kuchuk Kainarji in 1774 and the gradual domination of Russia over the Caucasus turned the transit trade of Iran into a big problem between the Ottoman Empire and Russia in the following period. In this study, the course of the transit trade of Iran in the $19^{\text {th }}$ century will be evaluated with its development in different areas within the context of the policy measures taken by the Ottoman Empire to prevent the diversion in the transit trade and taken by Russia to attract this trade to its territory. Concordantly, the development of regional trade under this competition is aimed to be set forth using primary sources. The findings show that the commercial activities in the north of Iran were gradually seized by Russia, and the Ottoman government could not realize the attempts needed under the constraints it had, which resulted in and the emergence of alternative routes between the West and Iran.
\end{abstract}

Keywords: Ottoman Empire, Russia, the transit trade of Iran, $19^{\text {th }}$ Century, Eurasian Economic History.

Öz

\section{Yüzyılın İkinci Yarısında Rusya, Osmanlı Devleti ve İran Arasında İran Transit Ticaretinin Gelişimi}

İran transit ticareti hem Osmanlı Devleti hem de Avrupa ekonomileri için hammaddelere erişim anlamında büyük bir öneme sahip olmuştur. Bu ticaret 18. yüzyılın son çeyreğine kadar büyük ölçüde Osmanlı Devleti'nin kontrolündedir. 1774 yılındaki Küçük Kaynarca Antlaşması ile birlikte bu tekel hakkının kaybedilmesi ve Rusya'nın Kafkaslar üzerinde kurduğu tedrici hakimiyet, söz konusu transit ticaretin takip eden dönemde Osmanlı Devleti ve Rusya arasında büyük bir problem dönüşmesine neden olmuştur. Bu çalışmada İran transit ticaretinin 19. yüzyıldaki seyri, Osmanlı Devleti tarafindan bu transit ticaretin farklı bir güzergaha sapmasını önleme ve Rusya tarafından da

\footnotetext{
* Assistant Professor, Dokuz Eylül University, Faculty of Economics and Administrative Sciences, Department of Economics, İzmir/Turkey. E-Mail: mehmet.cetin@deu.edu.tr. ORCID: 00000002-6954-0908

(Makale Gönderim Tarihi: 02.04.2020 - Makale Kabul Tarihi: 28.11.2020)
} 


\section{Mehmet ÇETIN}

kendi topraklarına çekme şeklinde kendisini gösteren farklı sahalardaki politika tedbirleri bağlamında değerlendirilmektedir. Bununla birlikte bölgesel ticaretin bu rekabet süreci altındaki gelişimi, birincil kaynaklardan istifade ederek ortaya konulmaya çalışmıştır. Bulgular, İran'ın kuzeyindeki ticari faaliyetlerin tedricen Rusya tarafından ele geçirildiğini ve Osmanlı hükümetinin içerisinde bulunduğu kısıtlar bağlamında ihtiyaç duyduğu girişimleri gerçekleştiremediğini ve bunun sonucunda Batı ile İran arasında alternative güzergahların ortaya çıktığını göstermektedir.

Anahtar Kelimeler: Osmanlı Devleti, Rusya, Iran transit ticareti, 19. Yüzyll, Avrasya İktisat Tarihi.

\section{Introduction}

The Classical Age of the Ottoman foreign trade took place on three main axes; initially East-West including the trade between the Iran and the Ottoman Empire through the land, secondly North-South including the trade between Anatolia, Egypt and Syria, and finally North-South from Anatolia to the North of the Black Sea, then to Poland and the inner parts of Russia. Although the changes in the trade routes due to the geographical explorations caused great damage to the caravan trade passing over Iran and Syria, the Ottoman foreign trade continued to take place on these axes until the effects of Industrial Revolutions showed up ${ }^{1}$. Another area of great importance in the foreign trade of the Ottoman Empire was the Black Sea trade, which was held under its monopoly until 1774. Thus the Black Sea trade emerged from a regional market and started to occupy an important place in intercontinental trade. An important feature of this trade was the connection of the Silk Road with a secondary line extending to Anatolia via TabrizErzeroum-Trebizond route. This line was one of the most important routes of transit trade between the Ottoman Empire and Iran $^{2}$.

Although the wars with Iran during the $16^{\text {th }}$ century dealt a severe blow to bilateral trade and affected the economy and finances of both countries adversely, the commercial ties between the Ottoman Empire and Iran were of great importance for both countries starting from the foundation to the end of the $19^{\text {th }}$-century. Especially after Aleppo passed under the rule of the Ottoman in 1516-17, all the exit points of Iranian silk that were open to Europeans were taken over by the Ottoman Empire, and in the late $16^{\text {th }}$ century the Ottomans tried to incorporate the silk production centres in the north of Iran into their own rule ${ }^{3}$. While the Iranian raw silk was an important source of raw material for Ottoman crafts, Ottoman cities also constituted an important market for Iranian silk products. Besides, Iranian silk, exported to Europe through transit trade over Ottoman territory, was an important source of income for the Ottoman Empire. Likewise, the Iranian Treasury obtained a significant amount of gold and silver owing to this transit trade ${ }^{4}$. For, the main obstacle to the development of foreign trade in Iran was the geographical position of productive Northern States, preventing it from linking to the world's open seas due to wide deserts and high mountain ranges ${ }^{5}$. The expansionist policies of the Russians to the

${ }^{1}$ Pamuk 2003, pp. 68, 162.

${ }^{2}$ Tozlu 2002, p. 481; Kaleli 1998, p. 19.

${ }^{3}$ İnalc1k 2003, p. 131.

${ }^{4}$ İnalc1k 2009, p. 196; Pamuk 2003, p. 68.

${ }^{5}$ Issawi 1970, p. 18. 


\section{The Development of the Transit Trade of Iran in the Triangle of Russia}

south were effective in the re-opening of the Black Sea to international trade again. The Russians, who conquered Azov in 1739, gained the privilege of free trade in the Danube and the Mediterranean under the provisions of the Kuchuk Kainarji Treaty signed in 1774. After Russia, Austria, Britain, France and Prussia acquired similar rights, the Ottoman monopoly over the Black Sea was ended and the sea truly opened to international trade ${ }^{6}$.

The Iranian transit trade followed a fluctuating course in parallel with the historical development of the Black Sea trade. After the geographical discoveries in the $16^{\text {th }}$ century, the raids organized by the Cossacks in the following century and the conflicts between the Ottoman Empire and the Safavid caused both the Black Sea trade and Iranian transit trade to lose their relative importance ${ }^{7}$. The commercial development gained momentum thanks to enabling security in trade routes, re-opening the Black Sea to international trade and the policy of loading Iranian commercial goods into the ships from Trebizond instead of the Port of Bushire in the Persian Gulf by the United Kingdom to diminish the transportation costs $^{8}$.

The Russian route provided more advantages for merchants than the Ottoman route due to the implementation of the Russian economic policy from the early $19^{\text {th }}$ century to the 1830s. Especially in according with the decree declared in 1821, the merchants operating in the south of the Caucasus were exempted from all local taxes and liabilities, and the foreign goods were subjected to lower customs tax ${ }^{9}$. In 1832, the Russian government made it difficult for Britain and France to ship their goods to the region to protect their domestic producers and traders, and removed the exemptions regarding the south of the Caucasus. With the new regulation, it was thought that the merchants could reach Iran only through Sokhum, Tbilisi and the Caspian Sea route or Tbilisi and Tabriz route; however, these practices encouraged the use of the TrebizondErzeroum-Tabriz route ${ }^{10}$. Hereon, the Russians removed the tax of transition from the Tbilisi route in 1846, and the contraband of British goods into Russia and the convenience of custom procedures and quarantine provided by the Russians for Iranian goods increased the importance of the route passing through the Caucasus and Georgia, which was shorter than the Tabriz-Trebizond route ${ }^{11}$. Moreover, the Poti-Tbilisi railway and port projects carried out by Russia changed the transit trade of Iran to Russian-Caucasian route, which resulted in a competition between Trebizond and Poti to dominate over this transit trade in the third quarter of the $19^{\text {th }}$ century ${ }^{12}$. Karl Marx, on the other hand, saw this competition as a reflection of the process that started during the Crimean War and including the Indian Territory between Britain and Russia on the Iranian field and

\footnotetext{
${ }^{6}$ Bostan 1999, p. 305.

${ }^{7}$ Akgün 2000, pp. 3-5.

${ }^{8}$ Kütükoğlu 1986, pp. 98-99.

${ }^{9}$ Kaleli 2003, p. 3 .

10 Turgay 1982, p. 290.

11 Tozlu 2002, p. 483.

${ }^{12}$ Report by Consul Palgrave 1871, pp. 736-737.
} 
considered the competition between Trebizond and Poti as an implicit Anglo-Russian rivalry ${ }^{13}$.

In this study, the political and economic competition between the Ottoman Empire and Russia in order to gain control over the transit trade of Iran is evaluated through Ottoman archival documents and reports submitted to the British House of Commons by British regional consuls. This study differs from the previous studies in that it both refers to a larger source and elaborates the available information within this framework, and includes other geographical locations in the domain of transit trade. Accordingly, commercial developments arising from the competition process at the main stops of the transit trade route in the last quarter of the 19thcentury will be discussed in the following sections.

\section{Operation of the Transit Trade in the Ottoman Empire, Iran and Russia}

The trade of Iran with Europe was regulated by the Treaty of Turkmenchay signed in 1828 in the $19^{\text {th }}$ century. The treaty provided important concessions to Europeans in the trade of Iran. Commercial relations of Iran with other countries carried out on seven different routes; Bender Abbas, Bushehr and Mohammera in the south, Baghdad in the west, Tabriz, Resht and Astarabad in the north. Tabriz was the most important warehouse in the trade of Iran with the West. Shipment of the goods and all kind of commodity between Tabriz and Europe were carried out on two lines. The first and the most important line was the Ottoman route that reached Trebizond through Tabriz-Bayezid-Erzeroum route. The total length of this route was about $770 \mathrm{~km}$. The second line was the Caucasus route controlled by the Russians ${ }^{14}$. While it took 35-40 days for the caravans to arrive from Tabriz to Trebizond, it took less time from Tabriz to Poti. Nevertheless, the fact that the shipment from Poti cost $10 \%$ higher practically equated the duration of the transportation in the middle of the $19^{\text {th }}$ century ${ }^{15}$.

Once the commercial connections through Trebizond were established, the development of this trade was determined by three elements; adequacy and cost of transportation in the Black Sea, sufficiency and cost of services in the Port of Trebizond and the Trebizond-Erzeroum-Tabriz route, and the level of competition of alternative routes and especially the Russian Transcaucasia route ${ }^{16}$. By the end of $1880 \mathrm{~s}$, ecopolitical conditions caused diversification of the routes where the transit trade took place. In this sense, in addition to Trebizond-Erzeroum route and the Tbilisi-Julfa route, which was also a Russian route, the route of Astarabad in the Caspian Sea and the southern route including Alexandretta, Aleppo, Mosul, Baghdad and Suleymaniye where the British goods were mostly transported emerged ${ }^{17}$. The following sections will be dealt with the segmentation of transit trade traffic for systematic treatment. General trend of the trade

\footnotetext{
${ }^{13}$ Marx and Engels 1977, p. 31.

${ }^{14}$ Tozlu 2002, p. 182; Report by Consul General Jones 1872, p. 255; Commercial No. 16 1876, p. 1487.

${ }^{15}$ Şaşmaz 2014, pp. 601-603.

${ }^{16}$ Issawi 1970, p. 19.

${ }^{17}$ FO Annual Series No. 798, 1890.
} 
in important commercial centres in the geographical regions classified as Iranian, Russian and Ottoman territories is indicated in the graph below.

Graph 1. Commercial Trend in the Main Stops of Iranian Transit Trade (million pounds)

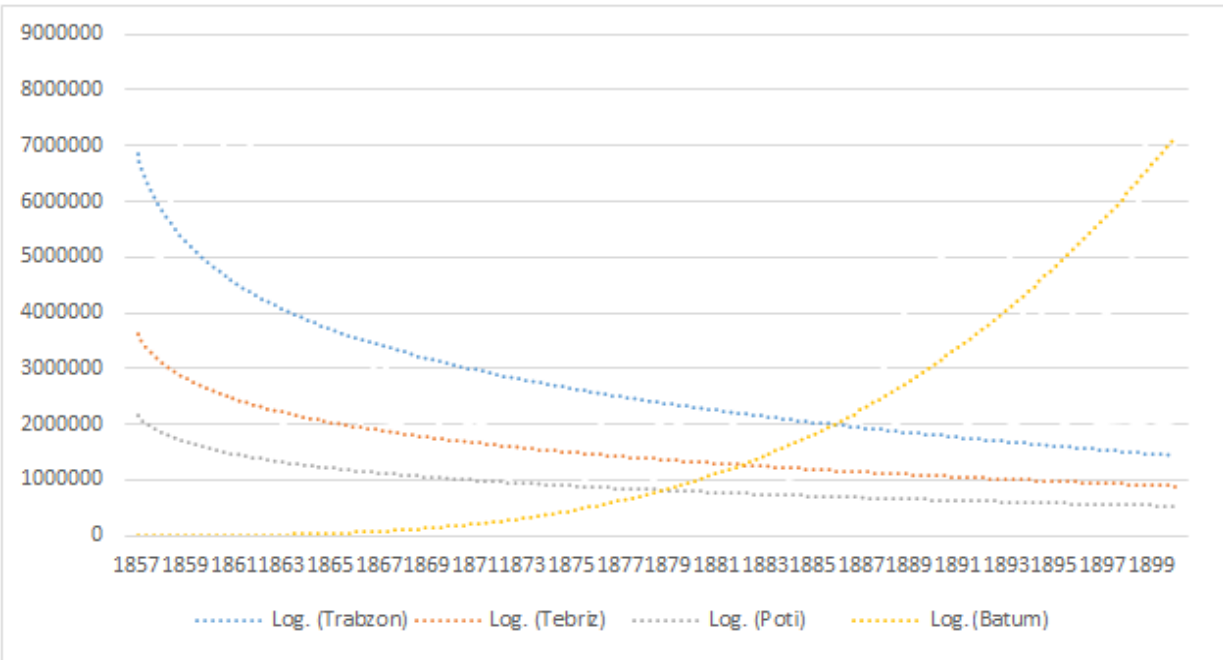

Source: Issawi 1970, p. 25; Reports from Her Majesty's Consuls (Compiled from different consular reports)

As can easily be seen from the graph, the total trade volume of Poti, developed by Russia as a rival to Trebizond, decreased over time, and the importance of Batoum increased rapidly as of the $1880 \mathrm{~s}$. The following sections cover the details of this brief explanation in three different territories in scope of the Ottoman and Russian competition.

\section{The Transit Trade in the Field of Iran}

Tabriz was the most important entrepot of the transit trade in Iran. It had land borders with both Ottoman and Russian territories, and it was the main market of Iran trade. Tabriz was also the capital of Azerbaijan which could be described as the most important province of Iran at the beginning of the second half of the $19^{\text {th }}$ century. Azerbaijan was the granary of Iran. In addition to this, the most important export goods were silk, and cotton especially produced in the province of Ghilan and dyestuffs from Western Iran. In the following period, tobacco, grown out of Turkish seed and exported to Russia for cigarette manufacturing, and mainly grown in Resht, took its place among other export goods. Import goods were essentially composed of clothing. Local industries in the region were limited in number and insignificant in production ${ }^{18}$. Istanbul was the

\footnotetext{
${ }^{18}$ Commercial No. 1 1875, p. 204; FO Annual Series No. 798, 1890.
} 


\section{Mehmet ÇETIN}

main stop of the trade performed from this region. Finished goods, which were mostly Manchester products, Marseillan candies and spices were largely imported from the Ottoman Empire while iron, steel, fragrance, ironmongery, wine, copper and porcelain were mostly imported from Russia ${ }^{19}$.

In the late 1850s, the volume of trade between the Ottoman Empire and Iran was 2,3 million pounds while the volume of trade between Russia and Iran was 435 thousand pounds. However, there was a 400 thousand-pound- contraband trade to Russia. The biggest share in foreign trade belonged to the United Kingdom. The impossibility of Russia to transport its abundant raw materials to the inner parts, and incapacity of its industry to provide cost advantage, especially when compared with the United Kingdom, limited the share of Russia in the foreign trade of Iran. One of the main obstacles to the development of the trade of Iran was the fact that the shipment was carried out with beasts of burden such as mules, horses, camels and donkeys, and internal custom taxes called Rahdarees. Every small town in Iran taxed the goods passing over them. This implementation discouraged the merchants because they caused the taxes on commodities to exceed the $\operatorname{cost}^{20}$. Apart from that, there was a serious money shortage that had spread throughout Iran for decades. Due to the weakness of the currency in Iran, the only currency available in the market was Russian kopecks which could only enable internal circulation $^{21}$. Both the currency uncertainties and the lack of a direct payment system between London, the financial centre of Britain, and Tabriz, were among the most important factors that disrupted commercial developments ${ }^{22}$.

At the beginning of the second half of the $19^{\text {th }}$ century, the export of silk was carried out by European merchants through Tabriz using the Ottoman route. However, this trade started to turn towards the Caspian route, which was from Enzella to Baku, and from there to the Russian route, reaching Tbilisi and Poti, by the end of the 1860s due to the incentives of the Russian government to reduce the freight costs of steamships in the Caspian Sea and the privileges granted in the customs tariff to attract the transit trade to the Russian territory ${ }^{23}$. The Russian route passing through the Caucasus was safer and cheaper than the Ottoman route passing through the Trebizond-Erzeroum road. Although the Poti-Tbilisi route was the best line considering the Russian transit trade policy, and the availability and speed of the means of transportation, the merchants had to send their goods to Trebizond or Busehr, or to Baghdad when it was too heavy because of the customs officials' intervention in the commercial operation and maltreatment of the Iranians in Caucasus and Caspian region ${ }^{24}$. In the 1870 s, for goods weighing more than 90 tons, the Julfa route, $120 \mathrm{~km}$ away from Tabriz and Poti-Tbilisi route, was preferred instead of the Trebizond-Erzeroum route. Despite the cost disadvantage ( 50 shillings for

\footnotetext{
${ }^{19}$ Commercial No. 16 1876, p. 1487.

${ }^{20}$ Board of Trade No. 9 1861, pp. 59-61; Commercial No. 1 1875, p. 204; FO Annual Series No. $798,1890$.

${ }^{21}$ Report by Consul-General Jones 1873, p. 968; Commercial No. 1 1875, p. 204.

${ }^{22}$ Commercial No. 24 1878, p. 1696.

${ }^{23}$ Report by Mr. Consul Abbott 1867, p. 110.

${ }^{24}$ Commercial No. 16 1876, p. 1487; Commercial No. 43 1882, p. 495.
} 


\section{The Development of the Transit Trade of Iran in the Triangle of Russia}

70 tons of goods for the Erzeroum route and 43 shillings for the Russian route) most of the European merchants preferred to use Ottoman territory for the transit trade of Iran ${ }^{25}$. This was largely due to regional competition between the UK and Russia.

The transit trade of Iran in this field was performed as follows. All commercial goods including some exceptions were delivered to intermediaries called binektars by importers. These intermediaries (binektars) sold these goods to shop owners or retail merchants or delivered them to buyers in the country. When agreed on the terms of sale, the broker kept an account of the details which were sealed by the binektars and approved the specified conditions. If the broker was not personally recognized by the seller, the broker was obliged to find a guarantor for his identity and solvency. It was usual to import Russian imperial or Turkish liras when the need for money or lack of money supply arose in Iran. Iranian citizens paid only $2 \%$ tax over the value of the imported goods. Similarly, road tax to be paid in Khoi which was a border town on the route of Erzeroum was $3 \mathrm{kran}$ and 15 shahi $^{*}$ per load. From Tabriz to Tehran, 3 kran and 15 shahis was paid per camel while it was 2 kran and 15 shahis paid per horse. Payments to Europe were made by having the bills of exchange received from the Armenian merchants who were usually Russian citizens in Tbilisi or Odessa drawn by a banker in Odessa. Therefore, the banker made the payment to Europe in franc or sterling ${ }^{26}$. The table below contains the statistics on the transportation costs of goods shipped from Europe to Tabriz via the Port of Marseille.

Table 1. Mode and Cost of Journey from Marseille to Tabriz

\begin{tabular}{|c|c|c|}
\hline Route & Mode of Conveyance & Cost \\
\hline $\begin{array}{l}\text { Marseilles }- \text { Batoum, } \\
\text { touching Constantinople } \\
\text { and ports Asia minor }\end{array}$ & Steamship, 1st class & 14 sterling \\
\hline Batoum-Axtafa & Railway & 19 sterling \\
\hline \multirow[t]{5}{*}{ Axtafa-Julfa } & $\begin{array}{l}\text { Post: carriage- } 378 \text { versts, at } 8 \text { copecks } \\
\text { per verst. }\end{array}$ & 3 sterling 6 pence \\
\hline & Horses: four, at 3 copecks per verst & $\begin{array}{l}4 \text { sterling } 10 \text { shillings } 9 \\
\text { pence }\end{array}$ \\
\hline & $\begin{array}{l}\text { Present to drivers: } 25 \text { copecks at each } \\
\text { station-22 stage. }\end{array}$ & 11 shillings \\
\hline & Lodging at any stationper night & 2 shillings \\
\hline & Tolls, greasing wheels, \&c. & 1 sterling 14 shillings \\
\hline Julfa-Tabriz & $\begin{array}{l}\text { Two post-horses: at } 2 \text { krans } 10 \text { shahis, } \\
\text { per fersack }-21 \text { fersacks and gifts to } \\
\text { guide }\end{array}$ & $\begin{array}{l}1 \text { sterling } 5 \text { shillings } 7 \\
\text { pence }\end{array}$ \\
\hline Total & & $\begin{array}{l}26 \text { sterling } 2 \text { shillings } \\
10 \text { pence }\end{array}$ \\
\hline
\end{tabular}

\footnotetext{
${ }^{25}$ Report by Mr. Consul-General Jones 1871, p. 237.

* 20 shahis $=1 \mathrm{kran}, 10 \mathrm{kran}=1$ toman and 1 toman=8 shilling and 9 pence for the year 1873 .

${ }^{26}$ Report by Consul-General Jones 1873, pp. 370-371.
} 


\section{Mehmet ÇETIN}

1 farsack $=3,75$ miles. 1 miles $=1.609344 \mathrm{~km} .1$ versts $=1.0068 \mathrm{~km} .1$ ruble 100 kopeck. 1 sterling 7,35 paper ruble. Source: FO Annual Series No. 22911899.

One of the most important factors that determined the commercial role of Tabriz within that period was the silk harvests in Ghilan, which was the source of raw silk and had a critical importance in Tabriz's exportation. In addition to the economic depression caused by the Austro-Prussian War in 1866, the Civil War in the USA and cholera and famines that devastated the country from time to time, the harvest failure in the province of Ghilan affected the regional trade adversely. The silkworm disease lasted until the late 1860 s and by 1869 the value of the silk exports had fallen to $£ 198.461$. Because of the negligence of local authorities about the disease, it spread to Ghilan, Mazenderan and Astarabad regions in a short time ${ }^{27}$. Although new silkworm eggs had to be imported from Japan eventually, the quality of the silk obtained from these eggs was relatively ${ }_{10}{ }^{28}$. In the second half of the 1870 s, domestic producers directed their attention to tobacco cultivation since the silk production remained lower than the previous years. Another remedy applied to by the peasants for the failed silk harvests was to start the production of rice which was previously imported from the province of Mazandaran ${ }^{29}$. Likewise, another product that started to be cultivated in a large part of Iran was opium and poppy due to the chronic silk failures. Poppy cultivation was tried in different regions such as the provinces of Ghilan, Mazenderan, Ispahan, Yezd and Shiraz, and it was especially successful in Ispahan, Yezd and Shiraz ${ }^{30}$.

After Ghilan's silk trade was destroyed, many trade houses in Iran had to end their commercial activities ${ }^{31}$. The chronic failures in the silk harvest caused money scarcity in the region, which resulted in a significant decline in foreign trade across the state. In this case, the production of raw silk was minimized, and the rural producers left their lands and tried to protect themselves from financial exploitation by taking refuge in Muslim shrines because of the wrong and unfair taxation policy of the Iranian government ${ }^{32}$. Similarly, the financial bankruptcy of the Iranian government and the loss of the value of money caused by that brought about deterioration of the economic situation in the region. In the 1860s, the Russian government started to build the Port of Poti and tried to improve the transportation opportunities between the Black Sea and the Caspian Sea, and thus attempted to attract the transit trade to its own territories, which resulted in tightening of border controls and shrinkage of contraband trade which was an important source of income for $\operatorname{Iran}^{33}$.

The realization of the transit trade of Iran on the Ottoman route through the beasts of burden increased the effect of natural factors on the transit trade. High mortality rates

\footnotetext{
${ }^{27}$ Report by Mr. Consul Abbott 1871, p. 234; Report by Consul Abbott 1873, p. 362.

${ }^{28}$ Commercial No. 2 1876, p. 69.

${ }^{29}$ Commercial No. 131877 , p. 748.

${ }^{30}$ Commercial No. 3 1882, p. 48.

${ }^{31}$ Report by Consul-General Jones 1871, pp. 960-961.

32 Report by Mr. Consul Abbott 1871, p. 234.

${ }^{33}$ Report by Consul-General Jones 1873, p. 364.
} 


\section{The Development of the Transit Trade of Iran in the Triangle of Russia}

of the animals due to the epidemic diseases that emerged in the early 1870s had a narrowing effect on the transit trade. The decrease in the profitability of the transportation because of the quarantine implementation of the Ottoman government forced the transporters who were even Ottoman citizens to use Russian route from time to time. High mortality rates of the animals also negatively affected the economy of Iran whose exports were largely based on animal products. Although the transit trade of Iran cost less than the one through the Ottoman route thanks to the construction of the Poti-Tbilisi railway, the delays and financial losses caused by the negligence of Russian customs officials created a balancing effect on the additional $1 \%$ road tax enforced by the Ottoman government for the transit goods ${ }^{34}$.

At the end of the 1870s, the most important development affecting the transit trade of Iran was the Russo-Turkish War of 1877-1878. The war made it impossible for the transit trade to be carried out on the ordinary routes. The transportation costs between Trebizond and Tabriz increased from 500 piastres per cantar to 1.250 piastres per cantar after the war. The main reason for this situation was the employment of pack animals in the military service. Despite high transportation and time costs, local merchants had to ship their goods using the Baghdad-Kermanshah route. As a matter of fact, the volume of the transit trade decreased from 1,7 million pounds to 800 thousand pounds. As the export of silk met the half of imports of Iran from Europe, the failures in silk harvests aggravated the impact of failures in both micro and macro terms ${ }^{35}$. Although the commercial activities tended to return to their former levels after the war, political uncertainties caused an excess supply and a rapid demand contraction in the Iranian markets. The main factors resulting in the contraction of commercial activities in Iran in this period were such problems as adverse conditions the currency of Iran experienced, the chronic foreign trade deficit, the neglected state of the trade routes, the loss caused by the robbery on these routes, the obligation of foreign merchants to provide long-term credit in their relations with the locals ${ }^{36}$.

Although the foreign trade of the Tabriz region experienced a partial recovery in the early 1880 s, the global commercial recession began to deepen its effects in 1885 . Hence, it was explicitly stated in the British Royal Commission's report regarding Iran, which was working on the commercial recession in 1885, that the chronic foreign trade deficit still continued, and as a result there was a perpetual flow of precious metals outwards, chronic poverty prevailed in the local trade environments, small bankers abused their duties and engaged in black market actions, government did not make any efforts to take any permanent measures to fix the value of money, there was a lack of convenient roads for transportation with carriages, the route of the goods transported from Trebizond to Tabriz changed to other trade channels, and especially some regions supplying goods via the Black Sea tended to use the Persian Gulf gradually ${ }^{37}$.

\footnotetext{
${ }^{34}$ Report by Consul-General Jones 1873, p. 968.

${ }^{35}$ Commercial No. 24 1878, p. 1696.

${ }^{36}$ Commercial No. 21880 , p. 113.

${ }^{37}$ FO Annual Series No. 691886.
} 
The transit trade route, which followed the Trebizond-Erzeroum road in the previous periods, changed its route to a great extent and turned to the south in the 1890s. However, due to the high taxes imposed on the trade over the Persian Gulf in the 1890s, British imports, especially Manchester products, made a partial return to the TrebizondTabriz route. Apart from this, the share of Russia increased especially in the trade of Northern Iran. Oil and petroleum products obtained from the Caspian basin and Baku greatly contributed to this increase. At the end of the century, the American Civil War completely disrupted the commercial improvements in Iran. Manufacturers who did not have enough capital in this depressive commercial environment caused by the Civil War had to stop their production. There was no development in the field of transportation in almost half a century ${ }^{38}$.

Tabriz had the privilege of being a warehouse at the entrance of the European origin commodity into the northern provinces of Iran at the beginning of the last quarter of the $19^{\text {th }}$ century. The opening of the Suez Canal dealt the first blow to the superiority of Tabriz in this trade route, and Russia's prohibition of transit trade carried out through the Caucasus put an end to that. The goods which were subject to transit trade began to be shipped through Bushehr and Baghdad in the Ottoman territory. Manchester products, which were formerly imported through the Ottoman territory, turned to the south in order to benefit from cheaper freight charges and to take the advantage of shipment to Bushehr over the Persian Gulf. The rest of the European-origin goods were shipped from Baghdad and Hermenshah route. Isfahan and Shiraz took the role of being the warehouse of Iran from Tabriz at the end of the century. Transportation costs over the Bushehr route were almost half lower than the Trebizond-Erzeroum route ${ }^{39}$. Although there was no shortterm positive development in the export of Russian goods to Iran after the closing of the Caucasian route, the possession of the trade in the Northern Iran was completely taken by the Russians in the $1890 \mathrm{~s}^{40}$.

\section{The Transit Trade in the Field of Russia}

The usual route for the goods shipped to the market of Iran at the beginning of the $19^{\text {th }}$ century was the Persian Gulf. While this trade was almost entirely in the hands of Britain, seizure of the Caucasian by the Russian resulted in a kind of transit trade ${ }^{41}$. Russia, which is a neighbour with Iran, realized the gains of this trade in a short time and started to take various measures for the transit trade of Iran to take place through Georgia $^{42}$. The history of transit trade passing through the Caucasian isthmus began practically in the 1860 s with the construction of the Poti-Tbilisi railway. Since the Caucasians were captured by the Russians, the goods shipped to Iran until that date began to be sent via the Trebizond-Erzeroum route. Besides the time and cost advantage

\footnotetext{
${ }^{38}$ FO Annual Series No. 2291, 1899.

${ }^{39}$ FO Annual Series No. 1440 1894; Commercial No. 7 1885, pp. 1-7.

${ }^{40}$ Commercial No. 7 1885, pp. 1-7.

${ }^{41}$ Commercial No. 41 1883, p. 15.

${ }^{42}$ Kaleli 1998, p. 23.
} 


\section{The Development of the Transit Trade of Iran in the Triangle of Russia}

provided by the railway transportation, the liberal policies pursued by the Russian government caused the transit trade to turn to the Caucasian route ${ }^{43}$.

Even though the transit trade was reversed, and the goods from Trebizond to Iran were carried from here to the Caucasus and Georgia as it was difficult for the Caucasus and Georgia to import European goods due to the embargo imposed on Russia by the allied powers during the Crimean $\mathrm{War}^{44}$, the responsibility of securing the commercial and maritime interests of all nations in the Black Sea ports was allocated to Russia and the Ottoman Empire in accordance with the international law pursuant to the Treaty of Paris, which ended the Crimean War. In compliance with the requirements of Article 12 of the Convention, Russia added Poti as a fourth port to ensure the development of commercial transactions following already existing ports of Anapa, Sukhumi and Redutkale $^{45}$. In this sense, the most important ports in the Russian territory were Poti and Batoum in the province of Transcaucasia. Poti, which was under the Ottoman rule until the beginning of the 19th century, was conquered by the Russians in 1809 . Thanks to the start of the constructions of the Poti-Tbilisi railway in 1863 and a new port in 1868, Poti became the most important export point of Asiatic Russia and started to stand out as a successful alternative to the Trebizond route, especially towards the end of the $1860 \mathrm{~s}^{46}$. Despite this, Europeans gave consent to pay the Ottoman government a-2\%-transit tax and shipped their goods via Erzeroum instead of using the Poti route due to the endless formalities at Russians customs, the need for convenient roads and transportation difficulties. The main exported goods from Iran and the Caucasus which were shipped from Poti were raw silk, cotton, wool, silkworm eggs, cocoon, leather and herbal powders for insects. Poti's own export products consisted of corn and timber that were shipped directly to the United Kingdom. Exports were mostly made through the ports of Istanbul and Marseille. The main imported goods were sugar, coffee, spices, medicines, iron, machinery, hardware, cotton products, wool products, silk products, household goods and luxury goods. Contraband trade accounted for one-third of the total trade. The largest share in both export and import belonged to the $\mathrm{UK}^{47}$.

The British commodity sent to the Iranian market was first usually dispatched from Liverpool to Istanbul and from there to Trebizond or to Poti in Georgia via Russian Company Steamers from London. The freight charge of the first route ranged from 4 shillings 6 pence to 5 shillings per bale while the second route was between 5 shillings and 5 shillings 6 pence. The cost of transportation from Tabriz to Erzeroum through Trebizond varied from 30 shillings to 45 shillings per bale*. The time of arrival of the goods sent to Tabriz via Trebizond from the UK was between 50 and 65 days while it

\footnotetext{
${ }^{43}$ Commercial No. 15 1883, p. 21.

${ }^{44}$ Turgay 1994, p. 57.

${ }^{45}$ Correspondence Respecting the Regulations 1863, pp. 11-12.

${ }^{46}$ Report by Vice-Consul Wilkinson 1863, p. 353; Report by Mr. Consul Palgrave 1869, p. 396.

${ }^{47}$ Board of Trade No.10 1861, p. 11.

${ }^{*}$ According to Annual Series, No. 930, dated to 1891 the cost of transportation was given between 75-200 piastres equal to $13,6-36,3$ shillings per cantar. Thus, the cost of transportation declined to an important extent.
} 
took around 85 days through Tbilisi. Although there was no possibility to insure the goods shipped over the Ottoman route, the Russian Company undertook the responsibility of the shipment between Poti and Tabriz by the rate of 1,5\%. While all goods entering Iran were taxed at a rate of 5\%, Iran allowed Ottoman merchants to import their products over $4 \%$ tax as an act of kindness. Despite the facilities provided for the Russian route, the merchants preferred to send their goods through the Ottoman route, still imposing a- $1 \%$ tax on transit trade at the beginning of the $1870 \mathrm{~s}$, due to losses and delays caused by the negligence and indifference of Russian customs officials ${ }^{48}$.

In spite of the great importance given to Poti and the high expenditures made, the ships had to rest $3 \mathrm{~km}$ away at the sea since there was still no quay where they could embark and disembark the goods as the decade of the 1870 s began. Attempt of the Russian engineers to build a port at the mouth of the Rhion River was previously failed. Since the depth of the river rarely exceeded 4 feet, larger ships had to unload their cargo in the Harbour of Batoum on the Ottoman lands ${ }^{49}$.

The position of Russia in transit trade continued to improve thanks to better transportation opportunities. New roads, reaching from Tbilisi to the Black Sea, the Caspian Sea and to the Iranian border, were built in 1871, and the Poti-Tbilisi rail line, which was critical for commercial development, was opened in November 1872. While the transportation costs from Poti to Tabriz were 4 shillings for a bale weighing $1 \mathrm{cwt}^{*}$, the cost of transportation from Trebizond to Tabriz via caravans was 1 pound and 4 shillings for the same amount ${ }^{50}$. With the construction of the Poti-Tbilisi railway and the establishment of a regularly operating steamship line between the port of Marseille and Poti, the transit trade of Iran has partially turned to the Caucasus route. Despite these improvements, the inability to complete the construction of the port in Poti and the obstacles caused by the geography prevented the Russian investments in the region to come to fruition, and Poti, once considered to be the southern metropolitan of the Russian Empire, experienced a rapid decline ${ }^{51}$. The main reason of this situation was the political discomfort associated with the Eastern Question along with global commercial depression. Besides, the failure of the harvest and the low grain prices in the main markets, to which the goods shipped from Poti turned, fed this depression. Due to the rumour about a war, the people started to leave the towns and villages, and the population of Poti fell to $4500^{52}$.

In the late $1870 \mathrm{~s}$, the Russian government determined a new tax tariff. In addition to sugar-sweetened alcoholic beverages, stamp taxes at different rates and fire insurance

\footnotetext{
${ }^{48}$ Report by Consul-General Jones 1873, p. 364.

${ }^{49}$ Report by Vice-Consul Wilkinson 1873, p. 512; Commercial No. 22 1874, p. 1456; Commercial No. 13 1875, p. 1315; Commercial No. 16 1876, p. 1573.

${ }^{*} 1 \mathrm{cwt}$ (hundredweight $=112$ pounds $=50,8023 \mathrm{~kg}$.

${ }^{50}$ Issawi 1970, p. 23.

${ }^{51}$ Commercial No. 16 1876, p. 1573; Report by Vice-Consul Wilkinson 1873, p. 512; Commercial No. 13 1875, p. 1315.

${ }^{52}$ Commercial No. 15 1878, p. 759.
} 


\section{The Development of the Transit Trade of Iran in the Triangle of Russia}

taxes, it increased railway and ferry transportation fees at various rates ${ }^{53}$. The main reason of the heavy protective tariff implemented by the Russian government was to promote local production; for example, to support cotton mills and other manufacturing industries ${ }^{54}$. This was one of the protective measures before the repeal of the Caucasian transit trade. In this sense, the transit trade of Iran was also affected by the prevailing protective policies on foreign trade in that period. The increase of the tax on foreign goods had a devastating effect on the British commodities, especially the Manchester goods, and the share of France in the foreign trade of the Caucasus increased rapidly. While the bureaucratic problems in Poti continued in this period, Batoum was incorporated into the Russian rule as a result of the Russo-Turkish War of 1877-78, which resulted in the integration of Poti and Batoum ${ }^{55}$.

The most serious development that determined Poti's fate was the start of operation of Transcaucasia rail line in 1883. Especially the opening of the BatoumLamtredi line directed a significant part of the commercial traffic from Poti to Batoum. Therefore, the gain of Batoum was largely the loss of Poti. Despite this, Poti was able to compete, albeit limited, with Batoum owing to its proximity to Tbilisi and Baku ( 25 miles closer than Batoum), the presence of the most densely populated areas, which were Mingrelia, Guria and Imereti, in its hinterland, and high productive potential in these areas, in contrast to underdeveloped agricultural conditions in Poti ${ }^{56}$. The success of Batoum in competition with Poti was not only because of the naturally protected harbour it had but also because of certain special arrangements that artificially disrupt business life in Poti. Although Poti was closer to Baku than Batoum, the railway company applied equally high fees for transportation, the Russian Company of Navigation and Trade sent only a small number of steamships to the port of Poti, and it was only possible to embark and disembark goods at Poti Sea Port when the sea was tremendously calm ${ }^{57}$. Therefore, the trade volume of Poti and its share in the transit trade of Iran declined rapidly over time, and it gained an identity as a local port where some local products were traded. As a matter of fact, the goods exported from the port of Poti were limited to corn and manganese in the $1890 \mathrm{~s}^{58}$.

Another important port of the Russian territory was Batoum, which was incorporated into the Russian rule after the Russo-Turkish War of 1877-78. Pursuant to the Article 59 of the Treaty of Berlin of 1878 ending the War, the port of Batoum was granted a free port status, especially for commercial matters*. Following the Crimean War, the route of the Transcaucasia trade was shifted to Poti, and the port of Batoum

\footnotetext{
${ }^{53}$ Commercial No. 101879 , p. 258.

${ }^{54}$ Commercial No. 13 1880, p. 283.

${ }^{55}$ Commercial No. 21 1879, p. 1483.

${ }^{56}$ Commercial No. 19 1884, p. 526.

${ }^{57}$ Commercial No. 1 1886, p. 84.

${ }^{58}$ FO Annual Series No. 6771890.

* "Treaty between Great Britain, Germany, Austria, France, Italy, Russia, and Turkey for the Settlement of Affairs in the East: Signed at Berlin, July 13, 1878", Vol 2, No. 4, pp. 401-424. https://www.jstor.org/stable/2212670 (13.02.2020)
} 
started to replace Poti as Poti had previously replaced Redutkale. The main purpose of the Russian government was to turn the port of Batoum into the main shipping area of the region, connecting Batoum to the transit route of Tbilisi, Caspian States and Iranian caravans. Thus, not only the goods shipped through Poti but also the oil trade of Baku and the remaining share of Trebizond in the transit trade of Iran could be drawn to the port of Batoum ${ }^{59}$.

In the first half of the $1880 \mathrm{~s}$, the abolition of Transcaucasia transit trade was intensely discussed in Russia. With this policy measure, the main purpose of the Russian government was to replace the Manchester goods, which had the biggest share in the import of Iran, with its own manufactured goods and to monopolize the commercial activities in the north of Iran over time ${ }^{60}$. Transit trade in this region was considered by Russia as one of the most effective means of attracting foreign capital, and creating a trade traffic that will monopolize the Anatolian trade in the short term and the Indian trade in the distant future, albeit partially, after spreading commercial activities to all Transcaucasia. However, tax exemptions granted to foreign transit trade was completely against the interests of the Russian industry according to the producers of Moscow. Trade routes that were opened randomly to the East made it difficult for the Russian merchants to compete with Europeans in the Eastern markets ${ }^{61}$. According to Prince Gortchakoff, the current conditions reinforced Britain's desire to establish commercial and political domination in the region, and disrupted the Russian influence on the Caspian basin. The liberal newspaper, Golos, was of the opinion that the current transit trade practice was compatible with both the commercial interests of Moscow and the interests of the merchants in the Transcaucasus region. This view was also supported by the inhabitants of Tbilisi, Kars and other Transcaucasia towns. Termination of the free transit trade would also jeopardize their commercial activities. The Undersecretariat of Treasury also agreed with the maintenance of the current situation, for substantial sums had been transferred to the railway construction, and shareholders had been granted a-5\%-government guarantee. The Moscow newspaper stated that the former Trebizond route could not be an alternative to the Transcaucasian route again due to the high freight charges and the existence of a long and unsafe road. The Russian government, on the other hand, thought that the foreign goods which had been transported to Baku on railways and from there to Iran by steamships would be transferred to Russian Trans-Caspian region and Central Asia without any difficulty, and the disadvantageous situation would spread to other regions and thus the markets would be monopolized in such a manner that they exclude the Russian goods ${ }^{62}$.

The opening of the Transcaucasus railway was an important step in the history of the Caucasus. On the other hand, trade seriously suffered from the ban on the trade of foreign goods in commercial traffic between the Caspian and the Black Sea. The Transcaucasus rail line was designed with opinion that it would improve transit trade. The

\footnotetext{
${ }^{59}$ Commercial No. 36 1882, p. 1089.

${ }^{60}$ Commercial No. 3 1884, p. 36.

${ }^{61}$ Commercial No. 10 1883, p. 202.

${ }^{62}$ Commercial No. 15 1883, p. 24.
} 


\section{The Development of the Transit Trade of Iran in the Triangle of Russia}

transit trade was so integrated with other local commercial activities, shipping and transportation business of the region that the sudden abolishment of the transit trade created a severe economic gap. The loss of time and money caused by the quarantine established due to the risk of cholera carried by the Egyptian origin ships entering the port of Batoum, widespread financial difficulties all around the country and economic depression were also effective in the contraction of commercial activities. Although the construction of the Transcaucasus rail line caused a significant part of the commercial traffic to be transferred from Poti to Batoum, moving the military headquarters to Kutaisi and more importantly, the abolishment of the Transcaucasian transit trade, which eliminated the free port status of Batoum, also affected the trade of Batoum negatively in addition to the above-mentioned reasons ${ }^{63}$.

Petroleum and petroleum-related raw materials, and finished goods had been the main components of trade through Batoum starting from this period. The port of Batoum became the most important shipping centre of Transcaucasia, and also the main station of the route from Europe to Iran ${ }^{64}$. The abolition of the free port status of Batoum by the Russian government caused controversy among the countries which were party to the Treaty of Berlin of 1878. Britain argued that no nation could free itself from an agreement to which it was a party according to the London Protocol of 1871 . However, Russia claimed that the port of Batoum was granted a free port status in order to improve the transit trade and the welfare of a region that had just been incorporated to the Russian rule. It also justified that Batoum could not have the commercial importance it had before the abolishment of the Caucasian transit trade after eight years of experience, and thus did not meet the expectations. As a matter of fact, after the abolition of the Caucasian transit trade, Batoum lost its characteristic of being the warehouse of the goods exchanged between the European states and Iran, and it remained only a port of importation. This provided the Russians required grounds for revoking the relevant free port status ${ }^{65}$.

Indeed, by the 1890s, the business life in Batoum was completely limited to the storage, conversion, manipulation and dispatch of the imported commodity. The import trade was arranged according to the demands of the oil industry, considering the type of commodity ${ }^{66}$. Although the prosperity the port of Batoum reached thanks to the oil of Baku lasted until the end of the century, the port of Novorossiysk started to be accepted as the exit port of Baku oil by the oil exporters due to the disruptions caused by the floods in Transcaucasia in certain regions of Baku-Batoum railway and the facilities provided by the Vladikavkaz railway company. Hence, the oil and its derivatives began to be transferred from Baku to the port of Novorossiysk via Petrovo using ferries on the Caspian Sea and to Validkavkaz using the railways ${ }^{67}$.

\footnotetext{
${ }^{63}$ Commercial No. 19 1884, p. 526.

${ }^{64}$ FO Annual Series No. 261886.

${ }^{65}$ Russia No. 11886.

${ }^{66}$ FO Annual Series No. 8711891.

${ }^{67}$ FO Annual Series No. 2424 1899; FO Annual Series No. 2264 1900; FO Annual Series No. 2623 1901.
} 


\section{The Transit Trade in the Field of the Ottoman Empire}

The primary commercial focus in the Ottoman territory was the port of Trebizond which was the last stop of transit trade traffic, and Erzeroum as an important centre of the transit route. Four main elements affecting the trade traffic in the field were the Russians, Ottomans, Iranians and the Europeans. These four elements jointly determined the volume and the characteristics of the commercial activities as Russia and Europe were mostly on the import side while Iran and the Ottoman Empire were on the export side of the transit trade. The transit trade of Iran accounted for approximately $80 \%$ of the commercial traffic in the port of Trebizond. The reasons for the Trebizond-Tabriz trade route to rise were the British traders looking for a shorter route for the Iranian market, regular steamer services from Istanbul to Trebizond and the custom duties imposed by Russia on the transit trade passing through Georgia. A great part of the commercial activities carried out through the port of Trebizond was under the control of the following companies: Lloyd's from Austria, Fuadiye from the Ottoman, Black Sea from Russia and Messageries Imperialies from France. However, periodically Iran was in a comprehensive depression in both production and financial areas. A similar situation was also current for the Ottoman economy. Inner parts of the Anatolia were in a general burnout. As a matter of fact, Trebizond was losing its producer classes because of excessive taxation, usury, need for capital and poor management. Indigenous Greeks migrated to the Russian Caucasus to seek for subsistence while Muslims headed for Istanbul ${ }^{68}$.

The transit trade on the Ottoman territory was performed as follows. Many importers in Tabriz had representatives who followed the purchases in Istanbul and the shipment of European goods for them. The goods were sent directly to a broker representative in Trebizond. Upon the arrival of the consignment, the bales were opened and approved by a customs officer. After that, a certificate expressing the quality and the value of bales was issued. The broker then provided a guarantee and evidence that the goods would be shipped to Iran. The goods were passed through the Ottoman border after a reasonable delay. In the absence of evidence, the goods were judged to be illegal, and a double tax up to $16 \%$ was demanded from the representative. Then the goods were sealed and sent to Erzeroum. The seals were examined here, and a certificate was given according to the situation. The goods were handed in to the charge of the caravan drivers after registering which goods were delivered to which caravan. In practice, the shipment process may not have corresponded to these stages one to one. For, when mid-winter came, snow and storms could affect shipping traffic, and the goods could often wait at the customs centre of Trebizond until the roads were re-opened. Although the Erzeroum route was more advantageous than the Poti route, the merchants preferred the Poti route instead of the Erzeroum route until the summer months due to the increase in transportation costs, especially in winter. Due to the transportation difficulties experienced in winter months, the price fora $-2,7 \mathrm{~kg}$ - best quality wheat could double when it was transferred to the port of Trebizond even though it was normally 16 shillings

\footnotetext{
${ }^{68}$ Report by Mr. Consul Palgrave 1870, p. 557; Board of Trade No. 11 1862, pp. 190-191; Report by Consul Palgrave 1871, pp. 736-737.; Kaleli 1998, p. 31.
} 


\section{The Development of the Transit Trade of Iran in the Triangle of Russia}

for the same amount ${ }^{69}$. Transportation costs from the province of Erzeroum to the surrounding areas are indicated in the table below.

Table 2. The Costs of Transportation from Erzeroum to Principal Routes of Trade

\begin{tabular}{|l|l|l|l|}
\hline Route & $\begin{array}{l}\text { Time } \\
(\text { days })\end{array}$ & Means & $\begin{array}{l}\text { Cost per 230 } \\
\text { kg (piastres) }\end{array}$ \\
\hline Erzeroum -> Trebizond & 10 & Horses, or country waggons & 100 \\
\hline Erzeroum-> Bitlis & $9-14$ & Horses, Waggon & $100-150$ \\
\hline Erzeroum-> Van & 12 & Waggon & $90-180$ \\
\hline Erzeroum -> Diyarbekir & 10 & Waggon & $80-120$ \\
\hline Trebizond -> Tabriz & 45 & Camels & $75-200$ \\
\hline
\end{tabular}

1 sterling $=110$ piastres, $300 \mathrm{lbs}=1$ Cantar $=230$ kilograms. Source: FO Annual Series No. 9301891

Eighty thousands of pack animals were used to carry out the transit trade on the Tabriz-Erzeroum-Trebizond route, two-thirds of the rental costs of which were collected by the Ottoman Empire. This rental was approximately 280 thousand pounds annually ${ }^{70}$. In addition to the high transportation costs, it was not common to find a sufficient number of pack animals. The importer was held responsible for the losses or theft that happened because of the negligence of the driver ${ }^{71}$. The only obstacle in the transit trade of Iran for the Ottoman Empire was not limited to the transportation problems. A significant obstacle arose from the customs regulations. Due to high port taxes, expensive licence fees and repeated government demands, even some of the Ottoman ship owners had to operate under the Russian flag ${ }^{72}$. In transit trade from the border of Iran to Trebizond, the customs fees for transport to Erzeroum was 3 cents per bale, while it was 5 cents per bale for transport to Trebizond. Whether any commercial representative resided in Erzeroum or Trebizond, he had to bear all transit custom fees with the commission of 8 piasters per bale $^{73}$. Bureaucratic procedures also rasped the advantages of Trebizond-Erzeroum route in the transit trade of Iran. The goods coming from Iran and exported to Europe via the port of Trebizond were tied, weighed and sealed at Trebizond customs. The goods were allowed to pass if the seals printed in Iran were still intact at Trebizond customs. Otherwise, the bales were re-evaluated, taxed again, and the correspondence process began for a new tender of amends to be sent. This implementation, which created great problems for all merchants, from large to small, could turn into a weapon in the hands of customs inspectors. It may have not been possible to keep the seal in its original form, especially in shipping via the seaway. The gross weights of the bales could vary as they were exposed to moisture and heat. Under these conditions, while a random package was

\footnotetext{
${ }^{69}$ Report by Mr. Consul Taylor 1868, pp. 575-582; FO Annual Series No. 10501892.

${ }^{70}$ Report by Mr. Consul Taylor 1866, pp. 218-225.

${ }^{71}$ FO Annual Series No. 1440 1894; Report by Mr. Consul Taylor 1868, pp. 575-582; FO Annual Series No. 10501892.

${ }^{72}$ Report by Consul Palgrave 1873, pp. 637-639.

${ }^{73}$ FO Annual Series No. 9301891.
} 
chosen for the most reasonable evaluation, the customs authority could command all bales to be opened. This bureaucratic disadvantage may have been the main reason why the Sublime Porte removed taxes on transit trade against Poti competition ${ }^{74}$.

The depression in the total trade volume of the port of Trebizond in the second half of the $19^{\text {th }}$ century was closely related with the transit trade of Iran. In this period, the prevailing stagnation in Iran, the decrease in the demand for Iranian goods in European markets, the failure of silk and cotton harvests and the drop off in their production, the environment of stagnation in commercial activities in Iran due to those mentioned above, adverse conditions in the European money markets, and above all, the gradual rise of a Russo-Iranian transit trade route via Poti underlay this decline in the trade of Trebizond. The efforts of Russia to attract the transit trade of Iran to its territory and to create an alternative route to the port of Trebizond, in this sense, started in the 1860s. To this end, the Russian government tried to create a duty-free trade route through Tbilisi and Poti, and for that, it started the construction of a new port in Poti in 1868. The Russian government signed up concessional contracts with Iranian merchants, allowing them to use Russian ships in their seas. The attempts of the Ottoman and French companies to break the Iran-Russia partnership failed. In addition, the Ralli Agency, which was established in 1858 to direct the Tabriz-Trebizond transit trade traffic, had to be closed because of insufficient business volume. Russian Poti-Tbilisi rail line and port attempts aimed at directing the trade of Iran to the Russian-Caucasian route. It was estimated that the Trebizond-Tabriz trade route would be a thing of the past, and Trebizond would fall into the position of small trade centres like Rizeh, Surmene and Kerassunde when the Russian-Iranian line started its operation, Resht and Baku, Elizabetphol lines became active, and the connection with the shore was established ${ }^{75}$.

Despite the trade traffic through the port of Trebizond maintained its importance in the European-Russian trade at the beginning of the last quarter of the $19^{\text {th }}$ century, the decrease in the use of Ottoman Empire-Iran route meant that the trade balance of interest changed in favour of Europe and Russia, and against the Ottoman Empire and Iran. Under this unfavourable course, the Ottoman government developed some plans to take measures to improve the road to Iran, and implement a decentralization system in Armenia similar to the newly established administrative system in the Danube. It also decided to reduce the tax on the transit trade from $2 \%$ to $1 \%$. In addition, the roads were covered and expanded in Meidan where the caravans from Iran unloaded their cargoes first. Finally, the Ottoman Government made some other attempts such as repairing Trebizond-Erzeroum caravan road, which was the main artery of the transit trade of Iran, and also disproportionally expensive due to the fact that it was previously in the form of a pack trail, and unsafe due to the fact that the entire bales had to be carried on the back of the horse, mule and camel to keep and revive the transit trade on Trebizond-Erzeroum route. However, another dimension of the case was that in case the Iran did not build a road lying towards the Ottoman border, the benefit expected from the construction of the

\footnotetext{
${ }^{74}$ Commercial No. 22 1874, p. 1602.

${ }^{75}$ Report by Consul Palgrave 1871, pp. 736-737; Report by Mr. Consul Gifford Palgrave 1869, pp. 429-433.
} 


\section{The Development of the Transit Trade of Iran in the Triangle of Russia}

Trebizond-Erzeroum route could not be obtained, and the carriages could not replace the pack animals ${ }^{76}$.

The Ottoman Empire was closely following the attempts by the Russians to turn the transit trade of Iran into its own route. The first initiative was made by Arif Pasha, the Governor of the Vilayet, in 1856. He planned a macadam road between TrebizondErzeroum and Tabriz. His efforts were appreciated by the government, but yielded no results. The Ottoman Government prepared three regulations about the TrebizondErzeroum and Iranian road in 1861 and $1869^{77}$. In a letter sent to the Ministry of Interior by Mustafa Pasha, who was the consultant of the $4^{\text {th }}$ Army in 1869, it was reported that the Russians made great efforts to repair the road between Poti and the border of Iran, so the construction of the road between Trebizond and Erzeroum was supposed to be accelerated, and could be completed in two years with about five thousand workers ${ }^{78}$. In the following year, Mustafa Pasha sent a telegram to the Seraskerat (War Ministry) informing that the road between Trebizond and Erzeroum would be macadamized, and the number of workers were increased to $5.798^{79}$. Subsequently according to an unsigned and unsealed Ottoman document dated 1872, the Russian government planned to build a rail line between Poti and Tbilisi, and even half of it was completed. From then on, it became more important whether Russia or the Ottoman Empire would control the transition point of the transit trade. Although the Ottoman Empire had previously attempted to build a carriage road towards the Iranian border with the concern that the transit trade would be conquered by the Russians, the situation was even more devastated by the Russian rail line initiative. The Trebizond-Erzeroum route, which was regularly maintained before, was neglected due to various obstacles. If this negligent attitude had continued, another path would have necessarily been sought for the Iranian merchants since the Trebizond-Erzeroum road would become completely impassable. The government allocated 160 thousand piastres for 4 roads to be rebuilt from Samsun to Amasya, from Ordo to Kastamoni, from Kerassunde to Kura and from Batoum to Kars, and also allocated the same amount for the maintenance and administration of the Erzeroum route from the state budget of 1872 . However, since 130 thousand piastres had already been spent for the construction of the military road in 1871, it was clear that 160 thousand piastres would not be enough. Even though a company was planned to be established to facilitate and organize the transportation of commodities and goods through the Erzeroum route, and the Imperial Ottoman and Austrian Banks promised to support this initiative, they withdrew due to the indifference of the Sublime Porte ${ }^{80}$.

Although the amount allocated by the government for the 200-mile-Erzeroum Trebizond route reached to 112.500 pounds in four years as of 1871 , this figure did not

\footnotetext{
${ }^{76}$ Commercial No. 22 1885, p. 1923.

${ }^{77}$ BOA, İrade Dahiliye (İ. DH.), 400/26466, H. 25.08.1274/M. 10.04.1858.

${ }^{78}$ BOA, İrade Dahiliye (İ. DH.), 598/41651, H. 02.06.1286/M. 09.09.1869.

${ }^{79}$ BOA, İrade Dahiliye (İ. DH.), 614/42780, H. 01.04.1287/M. 01.07.1870.

${ }^{80}$ BOA, Hariciye Nezareti Siyasi (HR. SYS.), 1363/16, H. 29.03.1289/M. 06.06.1872.
} 
cover some details. The table below indicates the details regarding the construction of the Erzeroum-Trebizond route ${ }^{81}$.

Table 3. Construction Costs of the Trebizond-Erzeroum Route

\begin{tabular}{|l|r|}
\hline Expense Items & Pounds \\
\hline Direct original outlay sanctioned by Government & 85.500 \\
\hline Supplementary Credit & 27.000 \\
\hline Subtotal & 112.500 \\
\hline $\begin{array}{l}\text { Compulsory employment of } 110.000 \text { men for 20 days, at 5 piastres per } \\
\text { day }\end{array}$ & 110.000 \\
\hline 1 oke of bread per day for each man for 20 days & 20.000 \\
\hline 10.000 carts for 20 days, at 10 piastres per day & 18.000 \\
\hline Bread for men attending carts and animals, 20 days & 3.600 \\
\hline Hired labourers and extras & 3.600 \\
\hline $\begin{array}{l}10 \text { per cent difference of money on the beshlik (5 piastre piece) passed } \\
\text { here at 5,5 piastres on 25.000 purses not accounted for to Government }\end{array}$ & 11.250 \\
\hline The actual cost of road paid out of Erzeroum revenues & 268.950 \\
\hline
\end{tabular}

Source: Report by Consul Taylor 1871, p. 1087

In order to complete the road until the end of August 1871, it was necessary to pay another 15 thousand pounds in return for compulsory and paid labour. Moreover, uninterrupted use of the road would not be possible. Since the iron-reinforced part was very limited, landslides in many parts would lead to additional costs. Likewise, 20 miles of the road passed over the mountain, which meant the road would not be easily used for civilian purposes due to avalanches ${ }^{82}$. Indeed, after the completion of the road, these discourses were seen to come true. Because of the narrowness of the road, the employment of pack animals and carriages in transportation simultaneously began to cause trouble. Even in some parts of the road two vehicles could not pass next to each other through the passages such as Kop and Zigana. Moreover, fatal accidents had also occurred since there were no roadside protection barriers ${ }^{83}$.

According to the correspondence between the Administration of Customs (Rüsumat Emaneti), the Ministry of Finance and the governor of the Province of Trebizond, the merchants who once used the Trebizond route to transfer their goods, tended to use the Poti route due to the road built by the Russian Government in Poti and $1 \%$ transit tax that was taken from the goods sent to Iran from Trebizond as it was not received on the Poti route. It was clearly stated in the correspondence that a regular carriage road was required to be built on the Trebizond-Erzeroum route in order to be able to compete with the route passing through Poti, and the transit tax to urge the

\footnotetext{
${ }^{81}$ Report by Consul Taylor 1871, p. 1072.

${ }^{82}$ Report by Consul Taylor 1871, p. 1072.

${ }^{83}$ Report by Consul Taylor 1873, p. 1122.
} 


\section{The Development of the Transit Trade of Iran in the Triangle of Russia}

merchants to use Trebizond route was abolished. It was also mentioned that the merchant would have used Trebizond route again due to its proximity if the transit tax had been abolished. The annual income from the transit tax was around 700 thousand piastres as this income would have been deprived if the merchants had preferred the Poti route. Consequently, considering the economic damage caused by the shift from the Trebizond route to the Poti route, it was decided to repeal the transit tax and revive this road ${ }^{84}$.

In the mid-1870s, the port of Poti could not be completed, but Poti-Tbilisi rail line and a new steamship line, operating directly from Marseille to Poti, for which the cost of freight was lower than the one on the Trebizond route were constructed. Thereby, the transit trade of Iran, already performed through Trebizond, had partially turned to the Caucasian route. Another disadvantage of sending goods to Iran through the TrebizondErzeroum route was that the caravans had to be paid even if there were no goods to be imported back. This situation caused the transportation costs to increase, which reduced the profitability of the transit trade. To get rid of these costs, the amount of the goods to be exported and imported had to be equalized and because of this, the European merchants started to prefer to send their goods with a $10 \%$ additional cost through the Poti route. Although the Ottoman government abolished the domestic customs from the trade realized on land in 1874 , this policy measure did not affect the transit trade. For, the main reason for the decline in transit trade was the poor transport facilities rather than the $\operatorname{taxes}^{85}$.

The most important development that affected the transit trade of Iran in the late 1870s was the Russo-Turkish War of 1877-78. The occupation of Kars, Ardahan and Batoum by the Russians deprived the port of Trebizond of a commercially important hinterland. The goods to be shipped to Iran through the port of Trebizond had to find alternative ways due to the war. The outbreak of the War at the beginning of the trade season caused the transit trade, which constituted the two-thirds of the trade of the port of Trebizond, to stop temporarily. The decrease in the number of transport vehicles prevented regular commodity transfer. All the Ottoman pack animals were taken into military service, and the Iranian caravans could not fill the gap. Hundreds of cargoes unloaded at the port of Trebizond had to be reshipped and sent to the Caucasus during their shipment to Iran. In the later stages of the war, the transit trade was completely stopped as Russia seized all Iranian caravans. Besides, thousands of pack animals died in the war, so the cost of transportation increased to an exorbitant level. The caravan fees increased from 2 pounds-2pounds 10 shillings per 180 okes of goods, to $7-9$ pounds in a short period depending on the shipping demands. The same price was 3 pounds and 10 shillings for Tbilisi. Few owners of pack animals had also opted for higher fees offered by the merchants rather than the low prices they were paid for the war service by the state. This situation led to an increase in transportation $\operatorname{costs}^{86}$.

\footnotetext{
${ }^{84}$ BOA, Sadaret Mühimme Kalemi Evrak1 (A. MKT. MHM.), 460/6, H. 04.06.1290/M. 30.07.1873.

${ }^{85}$ Commercial No. 22 1874, pp. 1628-1637; Commercial No. 11 1875, pp. 858-862; Commercial No. 9 1876, pp. 1087-1088.

${ }^{86}$ Commercial No. 19 1879, pp. 1019-1027; Commercial No. 42 1883, p. 2074.
} 
The Russian government determined a new and more protective tariff and enacted a law replacing the ordinary assurance paid at the customs for goods sent to Iran over the Russian territory with cash before the war ended ${ }^{87}$. According to this act, a bailing of one pound and four shillings per bale was requested for the commodity passing through the Russian territory. A commercial company which would bring five thousand bales a year had to pay 12 million rubles bail in a year. Since the beginning of the Russo-Turkish War of 1877-78, major commercial companies started to use the Persian Gulf and BaghdadKhermanshah route. The Ottoman Empire also built its policy on the transit trade of Iran on this line. There were expectations that the provinces of Azerbaijan, Ghilan and Mazandaran could be annexed by the Russians. Since a significant part of the goods sent to Iran from Europe passed through the Suez Canal, the Red Sea and the Iranian border, a railway to be built from Baghdad to the Iranian border would greatly facilitate the commercial activities and reinforce the friendly relationships between the Ottoman Empire, Iran and the United Kingdom. Moreover, since such a route would attract the trade of Isfahan, Tehran and Tabriz, goods could be delivered to the vast Asian territories faster than Russian goods. However, this thought remained only as a project ${ }^{88}$.

Due to the fact that Lazistan and partly Armenia were left to Russia as a result of the war, and Russia stretched its strict customs practices at the end of the war, the transit trade which passed through the port of Trebizond and especially the British trade that constituted approximately $50 \%$ of this trade was directed to the Russian route. Especially after the end of the Russo-Turkish War of 1877-78, the increase in banditry activities in Beyazid and Eleskirt regions also hit a serious blow to commercial life on the Ottoman route. In this sense, the transit trade started to be carried out by taking Poti to the centre since the end of the $1870 \mathrm{~s}^{89}$.

The stagnation in the commercial transactions in the port of Trebizond continued due to local political turmoil at the beginning of $1880 \mathrm{~s}$. In addition to the serious damage to the Trebizond-Erzeroum road, the Kurdish tribal raids through Iran caused the commercial concerns to increase in the region ${ }^{90}$. However, there was an unexpected increase in the transit trade of Iran. The main reason for this increase was the fact that Russia had banned the import of European origin goods that passed through the Transcaucasia, and the heavy penalties determined by the Tbilisi customs agency against looting deterred the merchants from using the Russian route. For this reason, some merchants started to use the Trebizond route to ship European products to Iran ${ }^{91}$. Upon this, the Ottoman Empire decided to provide some facilities to the merchants and Iranian citizens in customs practices to make them abandon the Poti route and use the TrebizondErzeroum route again. Accordingly, it was decided to bring a transit tax amnesty into effect, reduce the export tax to $1 \%$, increase the import tax from $6 \%$ to $8 \%$ and sign a new

\footnotetext{
${ }^{87}$ Commercial No. 19 1879, pp. 1022-1027.

${ }^{88}$ BOA, Hariciye Nezareti Tercüme Odas1 (HR. TO.), 464/7, H. 12.9.1295/M. 09.09.1878.

${ }^{89}$ FO Annual Series No. 1440 1894; Commercial No. 36 1880, pp. 1445-1453; Şaşmaz 2014, pp. 601-603.

${ }^{90}$ Commercial No. 27 1881, p. 1106.

${ }^{91}$ Commercial No. 28 1883, pp. 1127-1229; Commercial No. 42 1883, p. 2074.
} 


\section{The Development of the Transit Trade of Iran in the Triangle of Russia}

trade agreement with Iran. These tax rates were proposed to Iran, and it was agreed by both parties to keep it as a temporary arrangement between the two states until a new agreement signed $^{92}$.

Despite the facilities provided by the Ottoman government in practice, the goods had to be reshipped to Tbilisi by ships since the Trebizond-Erzeroum road did not allow the goods disembarked at the port of Trebizond to be transferred to Iran via Erzeroum in the 1880s. However, since the Russian government abolished the Transcaucasian trade, and the Trebizond-Erzeroum road was also unusable, this shipment started to be carried out over the Persian Gulf with a loss of time and additional costs. The port of Trebizond could only keep on its role in the transit trade of Iran to some extent due to the proximity to the north western regions of Iran ${ }^{93}$. The decline in demand for Iranian goods due to the commercial stagnation prevailing in Europe in the 1880s was also one of the primary reasons narrowing the transit trade ${ }^{94}$.

The main issues affecting the Iranian transit trade through the TrebizondErzeroum route in the 1890s were ongoing transportation problems, periodical epidemic problems and political instabilities. Although the share of the Ottoman route in the transit trade varied from time to time, high transportation costs, the cholera diseases that reached Trebizond through Bengal, Afghanistan or Balochistan and Russia or Iran, strict quarantine measures implemented due to this disease and even the interruption of the repair of Trebizond-Erzeroum road due to cholera had adversely affected the land and sea transportation, and ultimately the trade of $\operatorname{Iran}^{95}$. The restrictions caused by the quarantine measures disappeared towards the mid-1890s, but there occurred a general distrust in the trade routes between Erzeroum and Van due to looting of some caravans. The Armenian events that took place towards the end of the century caused the insecurity to spread and deepened the commercial stagnation. The shocks experienced in the political field shook the credit market and caused the commercial life to become paralyzed. The trade volume remained insignificant as political hesitations prevented commercial interests to come true $^{96}$. As a result, while the Trebizond-Tabriz route, which reached the highest level in terms of the volume of the transit trade, constituted approximately $40 \%$ of Iran's total trade in the middle of the $19^{\text {th }}$ century, it fell below $10 \%$ by 1900 , and continued to exist without any leap until the $\mathrm{WWI}^{97}$.

\section{Conclusion}

In this study, the transit trade of Iran was handled together with its historical development in Iranian, Ottoman and Russian territories. The transit trade of Iran had always been of great importance for both the Ottoman Empire as a source of income, and

\footnotetext{
${ }^{92}$ BOA, Meclis-i Vükela Mazbataları (MV.), 5/75, H. 15.01.1303/M. 24.10.1885.

${ }^{93}$ Commercial No. 41 1883, p. 15; Şaşmaz 2014, pp. 855-856; Commercial No. 22 1885, pp. 19501952.

${ }^{94}$ Commercial No. 10 1886, pp. 561-564.

${ }^{95}$ Şaşmaz 2014, pp. 1201-1208.

${ }^{96}$ FO Annual Series No. 1680 1896, pp. 1-3; FO Annual Series No. 1864 1897, pp. 1-3.

${ }^{97}$ Issawi 1970, p. 24.
} 
Russia and European countries for a source of raw materials. The competition in transit trade which started with the gradual incorporation of the Caucasus into the Russian rule was shaped by the mutual moves of the parties who wanted to attract the transit trade to their own territories under their control. Iran took a relatively passive role in this trade triangle due to the economic difficulties it faced. At this point, rather than affecting the route of transit trade, it was interested in the increase of the trade volume. In this sense, Russia's attempts to develop the port of Poti, which wanted to create an alternative to the port of Trebizond, reflected an important stage in this competition. Even though the Russian government failed to raise the port of Poti to an expected level, it managed to reduce the transportation costs to a large extent thanks to intensive railway construction activities in Transcaucasia against the Ottoman route passing through Trebizond and Erzeroum.

Although the Ottoman Empire predicted that the Russian initiatives would attract transit trade from the Ottoman lands to the Russian lands, it was able to make much more limited moves. The government tried to create sufficient resources for the repair of the Trebizond-Erzeroum road, gradually removed the taxes it demanded from the transit trade and abolished the internal customs, but it could not prevent the partial shift in the transit trade. In periods such as the Russo-Turkish War of 1877-78, when both trade routes became unusable, alternative trade routes emerged in Southern Iran. However, incorporation of Batoum, which had a natural and secure port, into the Russian rule as a result of the War, made it more advantageous in terms of transit trade than Poti.

In conclusion, the fact that the Russian government abolished Batoum as a free port and prohibited transit trade through Transcaucasia caused a conflict among the Western countries, which re-defined the course of transit trade completely. The port of Batoum, which had completely been fed by the oil products of Baku, was replaced by the Novorosisk within time. While the commercial activities in the north of Iran came under the control of the Russians, the British competing with the Russians in the region turned to the route of Bushehr, Baghdad and Khermenshah in the Persian Gulf. The business volume of Trebizond-Erzeroum and Tabriz route narrowed considerably. In this sense, the Ottoman government could not develop effective measures to maintain its position in the transit trade. Further studies should focus on the competition between the Turkish Republic and Russia on the transit trade of Iran especially in the period following the WWI. 


\section{BIBLIOGRAPHY}

\section{a. Archival Sources}

Turkish Presidency State Archives of the Republic of Turkey - Department of Ottoman Archives (Devlet Arşivleri Başkanlığı Osmanlı Arşivi (BOA)

Hariciye Nezareti Tercüme Odası (HR. TO.), 464/7, H. 12.9.1295/M. 09.09.1878.

Sadaret Mühimme Kalemi Evrakı (A. MKT. MHM.), 460/6, H. 04.06.1290/M. 30.07.1873.

İrade Dahiliye (İ. DH.), 400/26466, H. 25.08.1274/M. 10.04.1858.

İrade Dahiliye (İ. DH.), 598/41651, H. 02.06.1286/M. 09.09.1869.

İrade Dahiliye (İ. DH.), 614/42780, H. 01.04.1287/M. 01.07.1870.

Hariciye Nezareti Siyasi (HR. SYS.), 1363/16, H. 29.03.1289/M. 06.06.1872.

Meclis-i Vükela Mazbataları (MV.), 5/75, H. 15.01.1303/M. 24.10.1885.

\section{The National Archives, Foreign Office (FO)}

Board of Trade No. 9 (1861), Report by Mr. Dickson, British Acting ConsulGeneral at Tabriz, on the Province of Azerbaijan and on the Trade of Tabriz for 1859, Abstract of Reports of the Trade, \&c., of Various Countries and Places, for the Year 1859, London: Printed by Harrison and Sons, pp. 59-61.

Board of Trade No. 10 (1861), Report by Captain Cameron, British Vice-Consul at Poti, on the Trade of the Ports of Poti and Redoubt Kale during the Year 1859, Abstract of Reports of the Trade, \&c., of Various Countries and Places, for the Year 1859 from Her Majesty's Consuls, London: Printed by Harrison and Sons, pp. 11-12.

Board of Trade No. 11 (1862), Report by Mr. Stevens, British Consul at Trebizond, on the Trade, \&c., of that Pashalick, during the half-year ending 30th June, 1860, Abstract of Reports of the Trade, \&c., of Various Countries and Places, for the Years 1859, 1860 from Her Majesty's Consuls, London: Printed by Harrison and Sons, pp. 190-191.

Correspondence Respecting the Regulation Issued by the Russian Government in Regard to Trade with the Eastern Coast of the Black Sea (1863), London: Printed by Harrison and Sons.

Correspondence Respecting the Port of Batoum (1886), Russia No. 1, August 1886, London: Printed by Harrison and Sons.

Foreign Office (1886), Annual Series No. 69, Diplomatic and Consular Reports on Trade and Finance, Persia, Report for the Year 1885 on the Trade of Tabriz, London: Printed by Harrison and Sons.

Foreign Office (1886), Annual Series No. 26, Diplomatic and Consular Reports on Trade and Finance, Russia, Report for the Year 1885 on the Trade of Batoum, London: Printed by Harrison and Sons.

Foreign Office (1890), Annual Series No. 677, Diplomatic and Consular Reports on Trade and Finance, Russia, Report for the Year 1889 on the Trade of the Consular District of Batoum, April 1890, London: Printed by Harrison and Sons. 
Foreign Office (1890), Annual Series No. 798, Diplomatic and Consular Reports on Trade and Finance, Persia, Report for the Year Ending March 31, 1890, on the Trade of the District of Tabriz, London: Printed by Harrison and Sons.

Foreign Office (1891), Annual Series No. 871, Diplomatic and Consular Reports on Trade and Finance, Russia, Report for the Year 1890 on the Trade of the Consular District of Batoum, April 1891, London: Printed by Harrison and Sons.

Foreign Office (1891), Annual Series No. 930, Diplomatic and Consular Reports on Trade and Finance, Turkey, Report for the Years 1889-1890 on the Trade of Erzeroum, July 1891, London: Printed by Harrison and Sons.

Foreign Office (1892), Annual Series No. 1050, Diplomatic and Consular Reports on Trade and Finance, Turkey, Report for the Year 1891 on the Trade of the District of Erzeroum, May 1892, London: Printed by Harrison and Sons.

Foreign Office (1894), Annual Series No. 1440, Diplomatic and Consular Reports on Trade and Finance, Persia, Report for the Year 1893-94, on the Trade of the Province of Azerbaijan, London: Printed by Harrison and Sons.

Foreign Office (1896), Annual Series No. 1680, Diplomatic and Consular Reports on Trade and Finance, Turkey, Report for the Year 1895, on the Trade of Trebizond, London: Printed by Harrison and Sons.

Foreign Office (1897), Annual Series No. 1864, Diplomatic and Consular Reports on Trade and Finance, Turkey, Report for the Year 1896, on the Trade of the Trebizond Vilayet, London: Printed by Harrison and Sons.

Foreign Office (1899), Annual Series No. 2291, Diplomatic and Consular Reports, Persia, Report for the Year 1898-99 on the Trade and Commerce of Azerbaijan, London: Printed by Harrison and Sons.

Foreign Office (1899), Annual Series No. 2264, Diplomatic and Consular Reports, Russia, Report for the Year 1898 on the Trade of Batoum and District, London: Printed by Harrison and Sons.

Foreign Office (1900), Annual Series No. 2424, Diplomatic and Consular Reports, Russia, Report for the Year 1899, on the Trade of Batoum and District, London: Printed by Harrison and Sons.

Foreign Office (1901), Annual Series No. 2623, Diplomatic and Consular Reports, Russia, Report for the Year 1900, on the Trade of Batoum and District, London: Printed by Harrison and Sons.

Memoranda by Mr. J. G. Kennedy respecting Trans-Caucasian Transit Trade, Commercial No. 15 (1883), Reports from Her Majesty's Diplomatic and Consular Officers Abroad on Subjects of Commercial and General Interest, Part III, May 1883, London: Printed by Harrison and Sons, pp. 21-30.

Report by Vice-Consul Wilkinson on the Trade of Soukoumkale for the Year 1862 (1863), Commercial Reports received at the Foreign Office from Her Majesty's Consuls Between July 1st, 1862 and June 30th, 1863, London: Printed by Harrison and Sons, pp. 353-362.

Report by Mr. Consul Abbott on the Trade and Resources of the Province of Ghilan for the Year 1865, Commercial Reports received at the Foreign Office from Her 
Majesty's Consuls, During the Year 1866, August to December, February 1867, London: Printed by Harrison and Sons, pp. 103-110.

Report by Mr. Consul Taylor on the Trade of Erzeroum for the Year 1865, Commercial Reports received at the Foreign Office from Her Majesty's Consuls in 1866, London: Printed by Harrison and Sons, pp. 218-225.

Report by Mr. Consul Taylor on the Trade and Commerce of Erzeroum and Diarbekir for the Year 1867, Commercial Reports received at the Foreign Office from Her Majesty's Consuls in 1868, 31st July 1868, London: Printed by Harrison and Sons, pp. 575-582.

Report by Mr. Consul Gifford-Palgrave, on the Trade and Commerce of Trebizond for the Year 1868, Commercial Reports received at the Foreign Office from Her Majesty's Consuls During the Year 1868, August to December, February 1869, London: Printed by Harrison and Sons, pp. 429-443.

Report by Mr. Consul W. Gifford Palgrave, on the Provinces of Trebizond, Vias, Kastemouni and Part of Angora, Commercial Reports received at the Foreign Office from Her Majesty's Consuls, During the Year 1868, August to December 1869, London: Printed by Harrison and Sons, pp. 335-400.

Report by Mr. Consul Palgrave, on the Trade and Commerce of Trebizond for the Year 1869, Commercial Reports received at the Foreign Office from Her Majesty's Consuls in 1869-70, July 1870, London: Printed by Harrison and Sons, pp. 557-566.

Report by Mr. Consul Abbott, upon the Trade and Resources of the Province of Ghilan for the Year 1869, Commercial Reports Received at the Foreign Office from Her Majesty's Consuls in 1869-70, May 1871, London: Printed by Harrison and Sons, pp. 234-236.

Report by Mr. Consul-General Jones, on the Trade and Commerce of Tabriz for the Year 1870, Commercial Reports Received at the Foreign Office from Her Majesty's Consuls in 1869-70, May 1871, London: Printed by Harrison and Sons, pp. 237-241.

Report by Consul Palgrave, on the Trade and Commerce of Trebizond, Black Sea for the Year 1870, Commercial Reports Received at the Foreign Office from Her Majesty's Consuls in 1871, July 1871, London: Printed by Harrison and Sons, pp. 736740.

Report by Consul-General Jones, on the Trade of the Province of Azerbaijan for the Year 1870, Commercial Reports Received at the Foreign Office from Her Majesty's Consuls in 1871, August 1871, London: Printed by Harrison and Sons, pp. 960-961.

Report by Consul Taylor, on the Trade and Sheep and Cattle Farming of the Consulate of Koordistan during Year 1870, Commercial Reports Received at the Foreign Office from Her Majesty's Consuls in 1871, August 1871, London: Printed by Harrison and Sons, pp. 1072-1087.

Report by Consul General Jones, Tabriz, Reports Relative to British Consular Establishment 1868 \& 1871, Part IV, (Non-European Countries), 1872, London: Printed by Harrison and Sons, pp. 255-258.

Report by Consul Palgrave, on the Trade and Commerce of Trebizond during the Year 1872, Reports from Her Majesty's Consuls on the Manufactures, Commerce, \&c., 
of their Consular Districts, July 1873, London: Printed by Harrison and Sons, pp. 637639.

Report by Consul Taylor, on the Trade and Commerce of Koordistan for the Year 1872, Reports from Her Majesty's Consuls on the Manufactures, Commerce, \&c., of their Consular Districts, August 1873, London: Printed by Harrison and Sons, pp. 1122-1140.

Report by Mr. Consul Abbott, Resht, Reports by Her Majesty's Consuls on British Trade Abroad, Part II, 1873, London: Printed by Harrison and Sons, pp. 362-363.

Report by Consul-General Jones, Tabriz, Reports by Her Majesty's Consuls on British Trade Abroad, Part II, 1873, London: Printed by Harrison and Sons, pp. 364-382.

Report by Vice-Consul Wilkinson, on the Trade of Poti for the Year 1872, Reports from Her Majesty's Consuls on the Manufactures, Commerce, \&c., of Their Consular Districts, July 1873, London: Printed by Harrison and Sons, pp. 512-514.

Report by Consul-General Jones, on the State of Trade in the Province of Azerbaijan during the Year 1872, Reports from Her Majesty's Consuls on the Manufactures, Commerce, \&c., of their Consular Districts, August 1873, London: Printed by Harrison and Sons, pp. 968-972.

Report by Vice-Consul Biliotti, on the Trade of Trebizond for the Year 1873, Commercial No. 22 (1874), Reports from Her Majesty's Consuls on the Manufactures, Commerce, \&c., of Their Consular Districts, Part IV, London: Printed by Harrison and Sons, pp. 1628-1637.

Report by Consul-General Jones, on the Trade and Commerce of Tabriz for the Year 1873, Commercial No. 1 (1875), Reports from Her Majesty's Consuls on the Manufactures, Commerce, \&c., of Their Consular Districts, Part I, London: Printed by Harrison and Sons, pp. 204-207.

Report by Vice-Consul Biliotti, on the Trade and Commerce of Trebizond for the Year 1874, Commercial No. 11 (1875), Reports from Her Majesty's Consuls on the Manufactures, Commerce, \&c., of Their Consular Districts, Part I, June 1875, London: Printed by Harrison and Sons, pp. 854-868.

Report by Acting Vice-Consul Gardner, on the Trade and Commerce of Poti for the Year 1873, Commercial No. 22 (1874), Reports from Her Majesty's Consuls on the Manufactures, Commerce, \&c., on Their Consular Districts, Part IV, August 1874, London: Printed by Harrison and Sons, pp. 1456-1460.

Report by Consul Taylor, on the Trade and Commerce of Koordistan for the Year 1873, Commercial No. 22 (1874), Reports from Her Majesty's Consuls on the Manufactures, Commerce, \&co., on Their Consular Districts, Part IV, August 1874, London: Printed by Harrison and Sons, pp. 1602-1607.

Report by Acting Vice-Consul Gardner, on the Trade and Commerce of Poti, for the Year 1874, Commercial No. 13 (1875), Reports from Her Majesty's Consuls on the Manufactures, Commerce, \&co., on Their Consular Districts, Part V, July 1876, London: Printed by Harrison and Sons, pp. 1315-1320.

Report by Vice-Consul Biliotti, on the Trade and Commerce of Trebizond for the Year 1875, Commercial No. 9 (1876), Reports from Her Majesty's Consuls on the 
Manufactures, Commerce, \&co., on Their Consular Districts, Part IV, June 1876, London: Printed by Harrison and Sons, pp. 1079-1096.

Report by Acting Vice-Consul Gardner, on the Trade and Commerce of Poti for the Year 1875, Commercial No. 16 (1876), Reports from Her Majesty's Consuls on the Manufactures, Commerce, \&co., on Their Consular Districts, Part VI, August 1876, London: Printed by Harrison and Sons, pp. 1573-1577.

Report by Consul Churchill, on the Trade and Commerce of the Provinces of Ghilan and Asterabad for the Years 1874 and 1875, Commercial No. 16 (1876), Reports from Her Majesty's Consuls on the Manufactures, Commerce, \&co., on Their Consular Districts, Part VI. August 1876, London: Printed by Harrison and Sons, pp. 1487-1502.

Report by Consul Churchill, on the Silkworm Disease in Ghilan, Commercial No. 2 (1876), Reports from Her Majesty's Consuls on the Manufactures, Commerce, \&co., on Their Consular Districts, Part I, March 1876, London: Printed by Harrison and Sons, pp. 69-71.

Report by Consul Churchill, on the Trade and Commerce of Ghilan, Mazenderan, and Asterabad for the Year 1876, Commercial No. 13 (1877), Reports from Her Majesty's Consuls on the Manufactures, Commerce, \&c., on Their Consular Districts, Part III, June 1877, London: Printed by Harrison and Sons, pp. 748-761.

Report by Vice-Consul Gardner, on the Trade and Commerce of Poti for the Year 1876, Commercial No. 15 (1878), Reports from Her Majesty's Consuls on the Manufactures, Commerce, \&co., on Their Consular Districts, Part III, June 1878, London: Printed by Harrison and Sons, pp. 759-770.

Report by Consul-General Abbott, on the Trade and Commerce of Tabriz for the Year 1877-8, Commercial No. 24 (1878), Reports from Her Majesty's Consuls on the Manufactures, Commerce, \&co., on Their Consular Districts, Part V. August 1878, London: Printed by Harrison and Sons, pp. 1696-1698.

Report by Vice-Consul Biliotti, on the Trade, Commerce, and Navigation of the Port and District of Trebizond for the Years 1877-1878, Commercial No. 19 (1879), Reports from Her Majesty's Consuls on the Manufactures, Commerce, \&co., on Their Consular Districts, Part III, June 1879, London: Printed by Harrison and Sons, pp. 10161028.

Report by Mr. Plunkett, on the Finances of Russia, 1877-79, Commercial No. 10 (1879), Reports by Her Majesty's Secretaries of Embassy and Legation on the Manufactures, Commerce \&c., of the Countries in which They Reside, Part II, April 1879, London: Printed by Harrison and Sons, pp. 246-286.

Report by Acting Vice-Consul Carroll, on the Trade and Commerce of Poti for the Years 1877 and 1878, Commercial No. 21 (1879), Reports from Her Majesty's Consuls on the Manufactures, Commerce, \&co., on Their Consular Districts, Part IV, July 1879, London: Printed by Harrison and Sons, pp. 1483-1490.

Report by Consul-General Abbott, on the Trade and Commerce of the Province of Azerbaijan for the Year 1878-79, Commercial No. 2 (1880), Reports from Her Majesty's Consuls on the Manufactures, Commerce, \&c., of Their Consular Districts, Part I, February 1880, London: Printed by Harrison and Sons, pp. 113-116. 
Report by Consul Biliotti, on the Trade, Commerce, and Navigation of the Port and District of Trebizond for the Year 1880, Commercial No. 27, Reports from Her Majesty's Consuls on the Manufactures, Commerce, \&c., of Their Consular Districts, Part IV, July 1881, London: Printed by Harrison and Sons, pp. 1106-1129.

Report by Consul Biliotti, on the Trade, Commerce, and Navigation of the District of Trebizond for the Year 1879, Commercial No. 36 (1880), Reports from Her Majesty's Consuls on the Manufactures, Commerce, \&c., of Their Consular Districts, Part V, July 1880, London: Printed by Harrison and Sons, pp. 1445- 1454.

Report by Acting-Consul Lyall, on the Trade and Commerce of the Caucasian Provinces for the Year 1879, Commercial No. 13 (1880), Reports from Her Majesty's Consuls on the Manufactures, Commerce, \&c., of Their Consular Districts, Part II, March 1880, London: Printed by Harrison and Sons, pp. 278-283.

Report by Mr. Baring, on Trade and Cultivation of Opium in Persia, Commercial No. 3 (1882), Reports by Her Majesty's Secretaries of Embassy and Legation, on the Manufactures, Commerce, \&c., of the Countries in Which They Reside, Part I, February 1882, London: Printed by Harrison and Sons, pp. 48-62.

Report by Consul Biliotti, on the Trade and Commerce of the District of Trebizond for the Year 1884, Commercial No. 22 (1885), Reports from Her Majesty's Consuls on the Manufactures, Commerce, \& c., of Their Consular Districts, Part IX, August 1885, London: Printed by Harrison and Sons, pp. 1950-2026.

Report by Consul Biliotti, on the Trade, Commerce, and Navigation at Trebizond for the Year 1883, Commercial No. 28 (1883), Reports from Her Majesty's Consuls on the Manufactures, Commerce, \&c., of Their Consular Districts, Part VIII, August 1883, London: Printed by Harrison and Sons, pp. 1227-1253.

Report by Consul Alfred Biliotti, on the Trade, Commerce, and Navigation in the Vilayet of Trebizond from the Year 1873 to the Year 1882 inclusive, Commercial No. 42 (1883), Reports from Her Majesty's Consuls on the Manufactures, Commerce, \&c., of Their Consular Districts, Part XI, August 1883, London: Printed by Harrison and Sons, pp. 2073-2116.

Report by Vice-Consul Peacock, on Batoum and its Future Prospects, Commercial No. 36 (1882), Reports from Her Majesty's Consuls on the Manufactures, Commerce, $\&$ c., of Their Consular Districts, Part XIII, August 1882, London: Printed by Harrison and Sons, pp. 1089-1093.

Report by Mr. Dickson, on the Trade of Persia (1882), Commercial No. 43 (1882), Reports by Her Majesty's Secretaries of Embassy and Legation, on the Manufactures, Commerce, \&c., of the Countries in Which They Reside, Part VI, November 1882, London: Printed by Harrison and Sons, pp. 495-502.

Report by Vice-Consul Peacock, on the Proposed Abolition of the Transit Trade through Caucasus, Commercial No. 10 (1883), Reports from Her Majesty's Consuls on the Manufactures, Commerce, \&c., of Their Consular Districts, Part II, March 1883, London: Printed by Harrison and Sons, pp. 202-203.

Report by Vice-Consul Peacock, on the Trade and Commerce of Batoum for the Year 1883, Commercial No. 19 (1884), Reports from Her Majesty's Consuls on the 
The Development of the Transit Trade of Iran in the Triangle of Russia

Manufactures, Commerce, \&c., of Their Consular Districts, Part IV, April 1884, London: Printed by Harrison and Sons, pp. 526-532.

Report by Mr. Herbert, on the Effect of the Abolition of the Caucasus Transit Route on British Trade, Commercial No. 41 (1883), Reports from Her Majesty's Diplomatic and Consular Officers Abroad on Subjects of Commercial and General Interest, Part VIII, August 1883, London: Printed by Harrison and Sons, pp. 14-20.

Report by Mr. Dickson, on the Trade of Persia, Commercial No. 3 (1884), Reports by Her Majesty's Secretaries of Embassy and Legation on the Manufactures, Commerce, $\& c$., of the Countries in Which They Reside, Part I, February 1884, London: Printed by Harrison and Sons, pp. 33-40.

Report by Mr. Dickson, on the Trade of Persia, Commercial No. 7 (1885), Reports by Her Majesty's Secretaries of Embassy and Legation on the Manufactures, Commerce, \&c., of the Countries in Which They Reside, Part I, April 1885, London: Printed by Harrison and Sons, pp. 1-7.

Report by Consul Everett, on the Trade and Commerce of the Districts composing the Kurdistan Consulate for 1884, Commercial No. 22 (1885), Reports from Her Majesty's Consuls on the Manufactures, Commerce, \&c., of Their Consular Districts, Part IX, August 1885, London: Printed by Harrison and Sons, pp. 1923-1949.

Report by Vice-Consul Peacock, on the Trade and Commerce of Batoum for the Year 1884, Commercial No. 1 (1886), Reports from Her Majesty's Consuls on the Manufactures, Commerce, \&c., of Their Consular Districts, Part I, February 1886, London: Printed by Harrison and Sons, pp. 84-89.

Report by Consul Longworth, on the Trade and Commerce of Trebizond and Samsoon for the Year 1885, Commercial No. 10 (1885), Reports from Her Majesty's Consuls on the Manufactures, Commerce, \&c., of Their Consular Districts, Part IV, May 1886, London: Printed by Harrison and Sons, pp. 561-571.

\section{b. Published Sources and Works}

Akgün 2000

Necmettin Akgün, “Trabzon Gümrüğü’nde İktisadi Faaliyetler (1750-1850)", OTAM (Ankara Üniversitesi Osmanll Tarihi Araştırma ve Uygulama Merkezi Dergisi), 11, pp. 1-21.

Bostan 1999 İdris Bostan, “Karadeniz'in Dış Ticarete Kapalı Olduğu Dönemde Trabzon Limanı", Trabzon Tarihi Sempozyumu Bildirileri (6-8 Kasım 1998), (Prepared by K. Çiçek vd.), Trabzon: Trabzon Belediyesi Yayınları.

Issawi $1970 \quad$ Charles Issawi, "The Tabriz-Trabzon Trade, 1830-1900: Rise and Decline of A Route", International Journal of Middle East Studies, 1(1), pp. 18-27.

İnalcık 2003 Halil İnalcık, Osmanlı İmparatorluğu (Klasik Çăg, 1300-1600), 1. Bask1. (Translated by R. Sezer), İstanbul: Yap1 Kredi Yayınları.

İnalcık 2009 Halil İnalcık, “Tarihte Türk-İran Ekonomik Bağları Üzerine Bir Not" (Translated by G. Yavuzcan), Tarih Okulu, V, pp. 195-197. 


\section{Mehmet ÇETIN}

Kaleli 1998

Kaleli 2003

Kütükoğlu 1986

Marx and Engels 1977 Karl Marx and Friedrich Engels, Doğu Sorunu, Türkiye, (Translated by Y. Financ1), Ankara: Sol Yayınları.

Pamuk 2003

Şaşmaz 2014

Tozlu 2002

Turgay 1982

Turgay 1994

Hüseyin Kaleli, XIX. Yüzyılda Trabzon'da Ulaştırma Ekonomisi, Yayımlanmamış Doktora Tezi, Marmara Üniversitesi, İstanbul.

Hüseyin Kaleli, “19. Yüzyılda İran Transit Ticaret Yolu İçin Osmanl1-Rus Rekabeti”, Dumlupınar Üniversitesi Sosyal Bilimler Dergisi, 8, pp. 1-19.

Mübahat Kütükoğlu, "XIX. Yüzyılda Trabzon Ticareti”, Birinci Tarih Boyunca Karadeniz Kongresi Bildirileri, Ondokuzmayıs Üniversitesi Eğitim Fakültesi, Samsun, pp. 97-131.

Şevket Pamuk, Osmanlı-Türkiye İktisadi Tarihi, 1500 - 1914, 1. Baskı. İstanbul: İletişim Yayınları.

Musa Şaşmaz, Ingiliz Belgelerine Göre Trabzon Vilayeti Ticari Raporlarl, 1830-1914, Ankara: Türk Tarih Kurumu Yayınları.

Selahattin Tozlu, "Trabzon-Erzurum-Tebriz Yolu (XIX. Yüzyılda Sosyal ve Ekonomik Bakımdan Bir İnceleme)", Türkler, 14, Ankara: Yeni Türkiye Yayınları, pp. 481-492.

A. Üner Turgay, "Trade and Merchants in the Nineteenth Century Trabzon: Elements of Ethnic Conflict, Christians and Jews", Ottoman Empire: The Functioning of a Plural Society, 1, (Ed. B. Braude and B. Lewis), New York: Holmes and Meier Publishers Inc., pp. 287-313.

A. Üner Turgay, “Trabzon”, Doğu Akdeniz'de Liman Kentleri 1800-1914, (Ed. Ç. Keyder, Y. E. Özveren ve D. Quataert), İstanbul: Tarih Vakfı Yurt Yayınları, pp. 45-73.

\section{c. Internet Sources}

https://www.jstor.org/stable/2212670 (13.02.2020) 